\title{
Working Conditions and Anxiety. An Analysis on the Sixth European Working Conditions Survey Data
}

\author{
Nunzia Nappo \\ Università degli Studi di Napoli "Federico II" \\ Department of Political Science
}

\begin{abstract}
In 2015, the 16\% of the European workers experienced anxiety (EWCS 2017). Data show that anxiety disorders are the most prevalent mental health problems. According to the literature, poor working conditions hurt both physical and mental health. The paper studies the association between working conditions and anxiety for European workers (EU15), using data from the Sixth European Working Conditions Survey realised in 2017. The dependent variable is anxiety. Independent variables are selected taking into account that working conditions and support at work help to understand causes of anxiety. The association between working conditions and anxiety is tested using a standard probit model. Results show that high job demand increases anxiety and social support on the job reduces it.
\end{abstract}

Keywords: Anxiety; Working conditions; Job demand; Job support; Europe

\section{Introduction}

Anxiety disorders are the most prevalent mental health problems and are associated with conspicuous health care costs and a high burden of disease (Bandelow and Michaelis 2015). The Sixth European Survey on Working Conditions indicated that approximately the $16 \%$ of workers reported they experienced anxiety. Since most people spend the majority of their time working, "the workplace is one of the key environments that affect their mental wellbeing and health" (WHO 2000). The impact of work and working conditions on health may have a two-sided nature: from one side, the workplace can have positive effects on wellbeing providing social support, a sense of identity, and self-esteem; from the other side it also implies demands pressures, which, in turn, can induce anxiety (ILO 2016). However, it is difficult to assess the impact of work alone on anxiety, since it depends on numerous determinants and it can be general in nature.

Over the last decades, global competition, consequential shift in the aggregate demand and continuous technological progress have been producing deregulation of labour markets and the diffusion of nonstandard, flexible and precarious forms of employment, in many countries. Within firms, employers have been increasing pressure on workers both as regards requests of higher productivity and as regards loss of their autonomy in deciding order of tasks, methods of work and speed of work. In addition, the jobs crisis that followed the 2008 financial crash produced unemployment and a decline in the collective representation, which, in turn, helped employees to impose less favourable work and employment conditions. "This has had a largely negative effect on the quality of existing jobs" (Piasna 2017). In most European countries, those changes in the labour markets have been substantially transforming the experience of work and employment with serious implications for the (physical and mental) health and the well-being of workers.

Research (Karasek 1979; Karasek and Theorell 1990; Siegrist 1996) has explored the effects of working conditions on health reaching the conclusion that adverse working conditions hurt health, by contrast being employed with proper working conditions plays a protecting role both for physical and mental health. From a theoretical point of view, the key features of working conditions that influence mental health, also in the form of reported anxiety, are high job demand and low job control (Karasek 1979; Karasek and Theorell 1990). Job demand can be physical and/or psychological: the former regards manual work, the latter concerns the pace of work, the quantity and difficulty of work. By job decision latitude, or job control, is meant workers attitude to control their own activities and skills usage. According to the iso-strain model ("iso" stands for social isolation) the most hazardous situations take place when high strain (high job demand and low job control) is associated with low levels of social support within the workplace (Johnson and Hall 1988). 
Social support on the job can have a positive impact on mental health: good relationships with colleagues and with superiors may reduce (buffer) stressful situations (Baum 1999; McKenzie et al. 2002). According to the "demand-control-support" model, negative effects on (physical and mental) health are consequence not of a particular characteristic of work, but derive from the interaction between all demands related to work and workers power decision in facing those demands.

Mostly empirical research, which has as theoretical framework the iso-strain model, focused on the relationship between working conditions and physical health (among others Bosma et al. 1998; Cheng et al. 2000; Ostry et al. 2003; Niedhammer and Chea 2003; Warren et al. 2004; Datta Gupta and Kristensen 2007). However, several research (see among others de Jonge and Kompier 1997; Stansfeld et al. 1999; Demerouti et al. 2001; Sanne et al. 2005; Plaisier et al. 2007; Rusli et al. 2008) investigated on the relationship between working conditions and anxiety too, some of them are cross sectional studies. Furthermore, one of the main limitations of these studies is that they establish an association between working conditions and health, not a cause-and-effect relation without identifying a clear causal relationship in one direction or in the other. Therefore, causation could go in both directions, with workers who do not experience anxiety having more possibilities of good jobs, characterized by favourable working conditions, and with good working conditions improving workers' mental health (anxiety).

Exhaustive reviews of research on the Job Demand Control Support model with respect to psychological wellbeing (mental health) are provided by van der Doef and Maes (1999), by Ha"usser et al. (2010) and by de Lange et al. (2003). van der Doef and Maes (1999) analysed 63 studies, published in the period from 1979 to 1997. The authors reached the conclusion that the existing literature gives considerable support for the strain and iso-strain hypotheses, however, support for the moderating influence of job control, and social support is less consistent. Häusser et al. (2010) updated and extended van der Doef and Maes' review including 83 studies published between 1998 and 2007. When the sample size is sufficient, the authors found support for additive effects of demands, control, and social support on general psychological well-being almost always. However, there was consistent evidence for additive effects in relation to job-related well-being in cross-sectional studies, while support rates were lower in longitudinal data. Furthermore, evidence for interactive effects as predicted by the buffer hypotheses of the Job Demand Control Support model was very weak overall. The authors imputed such results on whether or not demands and control are based on qualitatively identical Job Demand Control Support dimensions (matching principle). de Lange et al. (2003) reviewed results of 45 longitudinal studies examining Karasek and Theorell's (1990) demand-control-support model. These studies provided only modest support for the hypothesis that the combination of high demands and low control implies high job strain. The authors found good evidence for lagged causal effects of work characteristics, particularly for self-reported health or well-being outcomes.

Different from other fields such as epidemiology, health psychology and sociology, working conditions and their impact on health status were not very much investigated in the economic literature (Barnay 2014; Fletcher et al. 2011). In relatively recent years, also economists started studying this topic given its impact on workers absenteeism and on workers productivity. Economists tend to agree with the idea of harmful effects of work strain on workers' health. Indeed, Cottini and Lucifora (2013), employing three waves of European Working Conditions Survey for 15 countries, found that adverse working conditions are strongly associated with workers' mental health problems. A strength of the research is that the authors addressed the potential endogeneity of working conditions and mental health within the workplace. Rodriguez (2002) and Bardasi and Francesconi (2004) focused on the effects of new employment schemes on health. Rodriguez (2002) using, panel data from Britain and Germany and a single measure of perceived health status dependent variable, reached the conclusion that the health status of part-time workers with permanent contracts is not significantly different from those who are employed full-time. In contrast, full-time employed people with fixed-term contracts in Germany are about 42 per cent more likely to report poor health than those who have permanent work contracts. Bardasi and Francesconi (2004) explored the relationship between individual wellbeing and atypical employment in Britain. Their results - on a panel of almost 7000 males and females workers from the first 10 waves of the British Household Panel Survey - show that atypical employment is not associated with adverse health consequences for either men or women. Warren et al. (2004) used data from the Wisconsin Longitudinal Study to study physical and psychosocial job characteristics as mediators in the relationship between socioeconomic status (SES) and health. The authors found that people with more physically and psychosocially demanding jobs have less favourable health outcomes. Robone et al. (2011) investigated on how contractual and working conditions affect health and psychological well-being employing twelve waves of the British Household Panel Survey. 
Results show that both contractual and working conditions affect health and psychological well-being with gender differences. Cottini (2012) investigated the relationship between health, working conditions and pay in Europe, employing the 2005 wave of the European Working Conditions Survey for 15 EU countries. Results show that, controlling for personal and firm characteristics (adverse) working conditions are associated with poor physical and mental health status. Llena-Nozal (2009) assessed empirically whether being employed or returning to work is beneficial in terms of mental health using longitudinal surveys for Australia, Canada, Switzerland and the UK. Results show that non-employment generally is worse for mental health than working. The mental health payoff to employment depends on the type of employment contract and on working conditions. Datta Gupta and Kristensen (2007) investigated whether a satisfactory work environment can promote employee health using panel model for Denmark, France and Spain. Results show that a good perceived work environment is a highly significant determinant of workers' health both for self-assessed general health and for the presence of a functional limitation.

The current paper studies the association between working conditions and anxiety for European workers, using data from the Sixth European Working Conditions Survey realised in 2017. The Survey presents the varied picture of Europe at work over time across countries, occupations, gender and age groups. The paper focuses on the EU15. Its theoretical reference is the Demand-Control-Support model (Karasek and Theorell 1990). The dependent variable is "anxiety" - a subjective indicator of mental health - collected through individual interviews. As regards independent variables, the selection of proper explanatory variables is driven by theory, moving from the idea that working conditions and support at work are two kinds of factors that help to understand causes of anxiety (Piccinelli and Wilkinson 2000; Wilhelm et al. 2004). The theoretical hypothesis concerning the association between working conditions and anxiety is tested using a standard probit model and outcomes of the econometric analyses describe a correlation rather than a cause-and-effect relation between working conditions and anxiety.

The main objective of this research is to investigate whether, controlling for several standard demographics variables, there is an association between some aspects of job demands, of job hazard, some job characteristics, several forms of social support within the workplace and reported anxiety. The original contribution of the paper to the literature is threefold. First, the study uses EWCS6 data to analyse the association between working conditions and anxiety. To the best of our knowledge, it is the first time that this release of the data has been employed for this kind of investigation. Second, the paper employs a broad definition of working conditions and, to the best of our knowledge, papers which have as dependent variable anxiety are very few. Third, the paper considers a large group of countries (EU15), while most studies focus on single countries or small groups of countries, so it extends the countries evidence on the association between working conditions and anxiety.

\section{Methods}

\subsection{Presentation of the data}

Individual data provided by the Sixth European Working Conditions Survey (2017) were employed in the econometric analysis. Data were accessed and downloaded via the UK Data Service. The Survey presents the varied picture of Europe at work over time across countries, occupations, gender and age groups. Since its launch in 1990, the European Working Conditions Survey has provided an overview of working conditions in Europe. A random sample of workers is interviewed face to face. Overall approximately 43.000 workers aged 15 and over, have been interviewed. The questionnaire includes topics related to employment status, working time duration and organisation, work organisation, learning and training, physical and psychosocial risk factors, health and safety, work-life balance, workers participation, earnings and financial security, as well as work and health.

The total number of countries in the sample is 35, including the EU28, Norway, Switzerland, Albania, the former Yugoslav Republic of Macedonia, Montenegro, Serbia and Turkey. No panel dimension is available. The econometric analysis focuses on EU15 countries and includes Austria, Belgium, Denmark, Finland, France, Germany, Greece, Ireland, Italy, Luxembourg, the Netherlands, Portugal, Spain, Sweden, the United Kingdom. After removing unselected respondents and missing variables on dependent and independent variables, the final data set is a cross-section sample and it consists of 13.257 observations. Table la provides the descriptive statistics for the sample. 
Table 1a: Descriptive Statistics of the Independent Variables

\begin{tabular}{|c|c|c|c|c|c|}
\hline Variable & Obs & Mean & Std. Dev. & Min & Max \\
\hline \multicolumn{6}{|l|}{ Demographics } \\
\hline Female & 21756 & .4952657 & .4999891 & 0 & 1 \\
\hline Age & 21722 & 44.06984 & 12.46566 & 15 & 88 \\
\hline $\mathrm{Age}^{2}$ & 21722 & 2097.536 & 1120.263 & 225 & 7744 \\
\hline Illness & 21660 & .2036011 & .402685 & 0 & 1 \\
\hline Middle level of education & 21663 & .5629414 & .496034 & 0 & 1 \\
\hline High level of education & 21663 & .2268845 & .418827 & 0 & 1 \\
\hline Has a child & 21761 & .4014981 & .4902126 & 0 & 1 \\
\hline Has a spouse or a partner & 21761 & .6248334 & .484177 & 0 & 1 \\
\hline Npeople & 21704 & 2.712956 & 1.303321 & 1 & 10 \\
\hline Permanent job & 21761 & .6517164 & .4764374 & 0 & 1 \\
\hline Full time job & 20441 & .7512842 & .4322793 & 0 & 1 \\
\hline \multicolumn{6}{|l|}{ Job demands } \\
\hline Complextasks & 21589 & .4878789 & .609477 & 0 & 1 \\
\hline High work intensity & 21656 & .6250462 & .4841222 & 0 & 1 \\
\hline Plus10 hours a day? & 21257 & .3381945 & .4731062 & 0 & 1 \\
\hline Sunday & 21500 & .3183256 & .4658374 & 0 & 1 \\
\hline Free time working & 21134 & .4606795 & .4984633 & 0 & 1 \\
\hline No break & 21456 & .173145 & .3783814 & 0 & 1 \\
\hline Repetitive work & 21596 & .4612891 & .4985108 & 0 & 1 \\
\hline \multicolumn{6}{|l|}{ Social support } \\
\hline Manager help & 17428 & .8289534 & .3765605 & 0 & 1 \\
\hline Manager job done & 17151 & .6579208 & .4744198 & 0 & 1 \\
\hline Colleagues cooperation & 17096 & .9907581 & .0956925 & 0 & 1 \\
\hline \multicolumn{6}{|l|}{ Job hazards } \\
\hline Handling infectious materials & 21676 & .1324506 & .3389879 & 0 & 1 \\
\hline Breathing smoke & 21685 & .1353931 & .3421509 & 0 & 1 \\
\hline Painful positions & 21698 & .4325744 & .4954444 & 0 & 1 \\
\hline Repetitive movements & 21705 & 6134992 & .4869588 & 0 & 1 \\
\hline Emotionally disturbing & 21686 & .2936457 & .455442 & 0 & 1 \\
\hline \multicolumn{6}{|l|}{ Job Characteristics } \\
\hline Private sector & 21068 & .7107462 & .4534267 & 0 & 1 \\
\hline Public sector & 21068 & .2323429 & .4223365 & 0 & 1 \\
\hline Joint private-public & 21068 & .0406303 & .197437 & 0 & 1 \\
\hline Health & 21207 & .4045362 & .4908136 & 0 & 1 \\
\hline Precarious work & 19121 & .4805188 & .4996334 & 0 & 1 \\
\hline Armed forces & 21697 & .0029958 & .0546532 & 0 & 1 \\
\hline Managers & 21697 & .063465 & .2438031 & 0 & 1 \\
\hline Professionals & 21697 & .193483 & .3950373 & 0 & 1 \\
\hline Technicians and associate professionals & 21697 & .1250403 & .3307723 & 0 & 1 \\
\hline Clerical support & 21697 & .099046 & .2987306 & 0 & 1 \\
\hline Service and sales & 21697 & .2121031 & .4088069 & 0 & 1 \\
\hline Skilled agricultural, forestry and fish & 21697 & .0321703 & .1764564 & 0 & 1 \\
\hline Craft and related trades & 21697 & .1031479 & .304159 & 0 & 1 \\
\hline Plant and machine operators & 21697 & .0583491 & .2344078 & 0 & 1 \\
\hline \multicolumn{6}{|l|}{ Country } \\
\hline Austria & 21697 & .0472405 & .2121577 & 0 & 1 \\
\hline Belgium & 21697 & .1188824 & .3236575 & 0 & 1 \\
\hline Denmark & 21697 & .0460457 & .2095889 & 0 & 1 \\
\hline Finland & 21697 & .0459997 & .2094893 & 0 & 1 \\
\hline France & 21697 & .0701714 & .2554415 & 0 & 1 \\
\hline Germany & 21697 & .0961812 & .2948464 & 0 & 1 \\
\hline Greece & 21697 & .0462754 & .2100858 & 0 & 1 \\
\hline Ireland & 21697 & .0485731 & .2149789 & 0 & 1 \\
\hline Italy & 21697 & .0644272 & .245518 & 0 & 1 \\
\hline Luxemburg & 21697 & .0460916 & .2096884 & 0 & 1 \\
\hline Netherlands & 21697 & .0472405 & .2121577 & 0 & 1 \\
\hline Portugal & 21697 & .0476541 & .2130381 & 0 & 1 \\
\hline Spain & 21697 & .1545885 & .3615202 & 0 & 1 \\
\hline Sweden & 21697 & .0460457 & .2095889 & 0 & 1 \\
\hline
\end{tabular}

\subsection{Dependent variable}

Our dependent variable is Anxiety. Anxiety is going to be considered as a subjective indicator of mental health, it has been collected through individual interviews. Interviewed responded to the question: "Over the last 12 months, did you have any of the following health problems?" Among others, Anxiety was one of the possible answers: responses could be expressed as Yes or Not. The $16.75 \%$ of the sample (21.761 observations) reported Anxiety over the last 12 months and the $85.80 \%$ of them were females. 


\subsection{Independent variables}

The selection of appropriate explanatory variables is driven both by theory and by the aim of the paper. The paper has as theoretical reference the Demand-Control-Support model (Karasek and Theorell 1990). This model implies three main dimensions - demand, control and reward - including the concept of support at work. Furthermore, a number of standard socioeconomic control variables are included in the econometric analysis. Table 1 provides a description of the independent variables used in the empirical model.

Table 1: Definition of the Independent Variables

\begin{tabular}{|c|c|}
\hline Variable & Description \\
\hline \multicolumn{2}{|l|}{ Demographics } \\
\hline Female & 1 if female; 0 otherwise \\
\hline Age and $\mathrm{Age}^{2}$ & Age in years at the time of the survey interview \\
\hline Illness & $\begin{array}{l}\text { 1if she/he has illness or health problem, which has lasted, or is expected to last, for more than } 6 \text { months, } 0 \\
\text { otherwise }\end{array}$ \\
\hline Middle level of education & 1 if highest level of education is secondary education, 0 otherwise \\
\hline High level of education & 1 if highest level of education is tertiary education, 0 otherwise \\
\hline Has a spouse or a partner & 1 if has a spouse or a partner, 0 otherwise \\
\hline Npeople & N. of people living in the household \\
\hline Permanent job & 1 if current job is permanent job, 0 otherwise \\
\hline Full time job & lif she/he works part time, 0 otherwise \\
\hline \multicolumn{2}{|l|}{ Job demands } \\
\hline Complextasks & 1 if main job involves complex tasks, 0 otherwise \\
\hline High work intensity & 1 if job involves working to tight deadlines, 0 otherwise \\
\hline Plus10 hours a day & 1 if during the month it happens that she/he works more than 10 hours a day at least once, 0 otherwise \\
\hline Sunday & 1 if during the month it happens that she/he works on Sunday at least once, 0 otherwise \\
\hline Free time working & 1 if over the last 12 months, she/he worked in her/his free time to meet work demands, 0 otherwise \\
\hline No break & 1 if she/he can take a break when she/he wishes, 0 otherwise \\
\hline \multicolumn{2}{|r|}{ 然 } \\
\hline Manager help & 1 if the manager helps and supports the worker, 0 otherwise \\
\hline Manager job done & 1 if the manager is helpful in getting the job done, 0 otherwise \\
\hline Colleagues cooperation & 1 if there is good cooperation between the worker and her/his colleagues, 0 otherwise \\
\hline \multicolumn{2}{|r|}{ (2) } \\
\hline Handling infectious materials & 1 if exposed to infectious materials, 0 otherwise \\
\hline Breathing smoke & 1 if exposed to smoke, fumes, powder or dust etc., 0 otherwise \\
\hline Painful positions & 1 if forced to tiring or painful positions, 0 otherwise \\
\hline Repetitive movements & 1 if forced to repetitive hand or arm movements, 0 otherwise \\
\hline Emotionally disturbing & 1 if exposed to situations that are emotionally disturbing, 0 otherwise \\
\hline \multicolumn{2}{|l|}{ Job Characteristics } \\
\hline Private sector & 1 if she/he works in the private sector, 0 otherwise \\
\hline Public sector & 1 if she/he works in the public sector, 0 otherwise \\
\hline Joint private-public & 1 if she/he works in a joint private-public company, 0 otherwise \\
\hline Health & 1 if the work affects health, 0 otherwise \\
\hline Precarious work & 1 if she/he might lose the job in the next 6 months, 0 otherwise \\
\hline Armed forces & 1 if she/he works in the armed forces, 0 otherwise \\
\hline Managers & 1 if she/he is a manager, 0 otherwise \\
\hline Professionals & 1 if she/he is a professional, 0 otherwise \\
\hline Skilled agricultural, forestry and fish & 1 if she/he is a skilled agricultural, forestry and fish worker, 0 otherwise \\
\hline Craft and related trades & 1 if she/he is a craft and related trades worker, 0 otherwise \\
\hline Plant and machine operators & 1 if she/he is a plant and machine operator, 0 otherwise \\
\hline \multicolumn{2}{|r|}{ (10) } \\
\hline Austria & 1 if the country is Austria, 0 otherwise \\
\hline Belgium & 1 if the country is Belgium, 0 otherwise \\
\hline Denmark & 1 if the country is Denmark, 0 otherwise \\
\hline Finland & 1 if the country is Finland, 0 otherwise \\
\hline France & 1 if the country is France, 0 otherwise \\
\hline Germany & 1 if the country is Germany, 0 otherwise \\
\hline Greece & 1 if the country is Greece, 0 otherwise \\
\hline Ireland & 1 if the country is Ireland, 0 otherwise \\
\hline Italy & 1 if the country is Italy, 0 otherwise \\
\hline Luxemburg & 1 if the country is Luxemburg, 0 otherwise \\
\hline Netherlands & 1 if the country is Netherlands, 0 otherwise \\
\hline Portugal & 1 if the country is Portugal, 0 otherwise \\
\hline Spain & 1 if the country is Spain, 0 otherwise \\
\hline Sweden & 1 if the country is Sweden, 0 otherwise \\
\hline
\end{tabular}

\subsection{The model}

The theoretical hypothesis concerning the association between working conditions and anxiety is tested using a standard probit model that is widely used to analyse discrete data of this type. The model takes the following form:

$P_{r}\left(Y_{i}=1\right)=\phi\left(x_{i} \beta\right)$

where $\phi$ represents the cumulative normal distribution function, $x$ is a vector of explanatory variables, $\beta$ is a vector of parameter estimates, subscript $i$ denotes an individual observation. 


\section{Results}

Before presenting the results, it is important to highlight that the outcomes of the econometric analyses, a crosssectional study (no panel dimension is available) describe a correlation rather than a cause-and-effect relation between working conditions and anxiety, and association does not imply causation. We do not identify a clear causal relationship in one direction or the other: it is reasonable to assume that causation goes in both directions, with the workers who experienced less problems of anxiety having more possibilities of being employed in good jobs, and with good working conditions decreasing workers' anxiety. However, the calculation of the marginal effects allows for interpreting the effect of the regressors on the dependent variable. Table 2 reports the probit estimates for Anxiety. A test for correct model specification was run. Table 3 reports the results.

Table 2: Correlates of Anxiety

\begin{tabular}{|c|c|c|c|}
\hline Regressors & Coeff & SE & $\mathbf{P}>|\mathbf{z}|$ \\
\hline \multicolumn{4}{|l|}{ Demographics } \\
\hline Female & $.1902398^{*}$ & .0336009 & 0.000 \\
\hline Age & $.0215199^{*}$ & .0090431 & 0.017 \\
\hline $\mathrm{Age}^{2}$ & $-.0002407 *$ & .0001053 & 0.022 \\
\hline Illness & $.5070397^{*}$ & .0346408 & 0.000 \\
\hline Middle level of education & $-.0910734 *$ & .0449233 & 0.043 \\
\hline High level of education & -.0460937 & .0565405 & 0.415 \\
\hline Has a spouse or a partner & $-.1236364 *$ & .0359816 & 0.001 \\
\hline Has a child & $-.1236364 *$ & .0359816 & 0.001 \\
\hline Npeople & $-.0367676^{*}$ & .0164234 & 0.025 \\
\hline Permanent job & .0507034 & .0425589 & 0.234 \\
\hline Full time job & -.0602377 & .0383155 & 0.116 \\
\hline \multicolumn{4}{|l|}{ Job demands } \\
\hline Complextasks & $.0810456^{*}$ & .0350802 & 0.021 \\
\hline High work intensity & $.0929297 *$ & .0346612 & 0.007 \\
\hline Plus 10 hours a day & $.1478643^{*}$ & .0348408 & 0.000 \\
\hline Sunday & $.0690101 *$ & .0341699 & 0.043 \\
\hline Free time working & $.1630545^{*}$ & .0325088 & 0.000 \\
\hline No break & $.0760853^{*}$ & .0369445 & 0.039 \\
\hline Repetitive work & $.2051118^{*}$ & .0321155 & 0.000 \\
\hline \multicolumn{4}{|l|}{ Social support } \\
\hline Manager help & $-.2914249^{*}$ & .0410511 & 0.000 \\
\hline Manager job done & $-.1579703^{*}$ & .0336365 & 0.000 \\
\hline Colleagues cooperation & $-.3568938^{*}$ & .1196586 & 0.003 \\
\hline \multicolumn{4}{|l|}{ Job hazards } \\
\hline Handling infectious materials & $-.1686457^{*}$ & .0446419 & 0.000 \\
\hline Breathing smoke & $-.0974035^{*}$ & .0478414 & 0.042 \\
\hline Painful positions & $.0721907 *$ & .034432 & 0.036 \\
\hline Repetitive movements & $.0796259^{*}$ & .0333508 & 0.017 \\
\hline Emotionally disturbing & $.365553 *$ & .0331908 & 0.000 \\
\hline \multicolumn{4}{|l|}{ Job Characteristics } \\
\hline Private sector & -.0931871 & .1054014 & 0.377 \\
\hline Public sector & -.1116846 & .1062653 & 0.293 \\
\hline Joint private-public & $-.3617346^{*}$ & .1264766 & 0.004 \\
\hline Health & $.4268356^{*}$ & .0310361 & 0.000 \\
\hline Precarious work & .0693597 & .0316448 & 0.028 \\
\hline Armed forces & .0164219 & .237318 & 0.945 \\
\hline Managers & $.3175613 *$ & .0886185 & 0.000 \\
\hline Professionals & $.2363056^{*}$ & .070552 & 0.001 \\
\hline Technicians and associate professionals & $.2303646^{*}$ & .0688034 & 0.001 \\
\hline Clerical support & $.3058852 *$ & .0689672 & 0.000 \\
\hline Service and sales & .1152892 & .062208 & 0.064 \\
\hline Skilled agricultural, forestry and fish & .0481018 & .1771195 & 0.786 \\
\hline Craft and related trades & .1046456 & .07532 & 0.165 \\
\hline Plant and machine operators & .0050336 & .0801649 & 0.950 \\
\hline \multicolumn{4}{|l|}{ Country } \\
\hline Austria & $-.9084634 *$ & .0994597 & 0.000 \\
\hline Belgium & $-.2103566^{*}$ & .0653556 & 0.001 \\
\hline Denmark & $-.9138619^{*}$ & .1027165 & 0.000 \\
\hline Finland & $-.5048898^{*}$ & .0863252 & 0.000 \\
\hline France & $.4662618^{*}$ & .0651558 & 0.000 \\
\hline Germany & $-.7885039^{*}$ & .0832035 & 0.000 \\
\hline Greece & $.8149385^{*}$ & .0825693 & 0.000 \\
\hline Ireland & -.043908 & .0804204 & 0.585 \\
\hline Italy & .0005886 & .0874128 & 0.995 \\
\hline Luxemburg & $.1573568^{*}$ & .0765344 & 0.040 \\
\hline Netherlands & $-.2563614^{*}$ & .1001625 & 0.010 \\
\hline Portugal & -.063635 & .062193 & 0.306 \\
\hline Spain & $-.2179423^{*}$ & .0785669 & 0.006 \\
\hline Sweden & $-1.348076^{*}$ & .2663824 & 0.000 \\
\hline Number of Obs & 13257 & & \\
\hline Pseudo R2 & 0.1949 & & \\
\hline Wald $\chi 2(54)$ & 1815.01 & & \\
\hline Prob $>\chi^{2}$ & 0.0000 & & \\
\hline
\end{tabular}


Table 3: Link test

\begin{tabular}{lrrr}
\hline $\boldsymbol{S A H}$ & \multicolumn{1}{c}{$\boldsymbol{C o e f f}$} & $\boldsymbol{S E}$ & $\boldsymbol{P}>|z|$ \\
\hline -hat & $1.061275^{*}$ & .0495593 & 0.000 \\
- $h a t s q$ & .0372618 & .0264014 & 0.158 \\
Number of Obs & 13257 & & \\
Pseudo R2 & 0.1950 & & \\
Prob $>$ 2 & 0.0000 & & \\
\hline
\end{tabular}

* Significant at $5 \%$ level of significance.

As said, in a standard probit, we interpret the sign of the coefficient but not the magnitude. Results show that females experience more anxiety problems than men do. Increasing age reduces anxiety problems. Workers who have an illness or a health problem, which has lasted, or is expected to last, for more than 6 months experience more anxiety problems than workers who do not. Workers who have middle education experience less anxiety problems than those who have elementary education. Workers who live with the partner report less anxiety problems than those who do not. Increasing the number of people living in the household decreases anxiety. Performing a main job that involves complex tasks and working to tight deadlines increase anxiety. Working more than 10 hours a day at least once a month and working on Sunday increase anxiety. Working in free time to meet work demands, working without taking a break when wished and monotonous tasks increase anxiety. Helps and supports by the manager and cooperation with the colleagues decrease anxiety. Exposition to infectious materials and to smoke, fumes, powder or dust etc. decreases anxiety. Tiring or painful positions and repetitive hand or arm movements increase anxiety. Exposition to situations that are emotionally disturbing increases anxiety. Working in a joint private-public company rather than in the not-for-profit sector or in an NGO reduces anxiety. Thinking that your work affects health and that you might lose the job in the next 6 months increases anxiety. Managers, professionals, technicians and associate professionals, clerical support workers experience more anxiety problems than workers who are employed in elementary occupations.

Tab 4 reports the marginal effect $(d x / d y)$ of a change in regressors on the probability of reporting anxiety. Marginal effects measure the expected instantaneous change in the dependent variable as a function of a change in a certain explanatory variable while keeping all other covariates constant. In a probit model, marginal effects are difficult to interpret as they are not equal to the coefficients, nor do their signs necessarily correspond to the signs of the coefficients (Long 1997). 
Table 4: Marginal Effects

\begin{tabular}{|c|c|c|c|}
\hline Regressors & $d y / d x$ & SE & $\mathbf{P}>|\mathbf{z}|$ \\
\hline \multicolumn{4}{|l|}{ Demographics } \\
\hline Female & $.0371702 *$ & .00655 & 0.000 \\
\hline Age & $.0045152 *$ & .0019 & 0.017 \\
\hline $\mathrm{Age}^{2}$ & $-.0000505^{*}$ & .00002 & 0.022 \\
\hline Illness & $.1172122 *$ & .00919 & 0.000 \\
\hline Middle level of education & $-.0179822 *$ & .00895 & 0.045 \\
\hline High level of education & -.0088842 & .01074 & 0.408 \\
\hline Has a spouse or a partner & $-.024647 *$ & .00732 & 0.001 \\
\hline Has a child & .0109667 & .00894 & 0.220 \\
\hline Npeople & $-.0071879 *$ & .00321 & 0.025 \\
\hline Permanent job & .0097191 & .00799 & 0.224 \\
\hline Full time job & -.0119961 & .00778 & 0.123 \\
\hline \multicolumn{4}{|l|}{ Job demands } \\
\hline Complextasks & $.01562 *$ & .00666 & 0.019 \\
\hline High work intensity & $.0178315^{*}$ & .00652 & 0.006 \\
\hline Plus10 hours a day & $.0178315^{*}$ & .00652 & 0.000 \\
\hline Sunday & $.0137217 *$ & .00691 & 0.047 \\
\hline Free time working & $.0323002 *$ & .00652 & 0.000 \\
\hline No break & $.0152835^{*}$ & .00762 & 0.045 \\
\hline Repetitive work & $.0405062 *$ & .0064 & 0.000 \\
\hline \multicolumn{4}{|l|}{ Social support } \\
\hline Manager help & $-.0638606^{*}$ & .00999 & 0.000 \\
\hline Manager job done & $-.0318215^{*}$ & .00698 & 0.000 \\
\hline Colleagues cooperation & $-.0847072 *$ & .03345 & 0.011 \\
\hline \multicolumn{4}{|l|}{ Job hazards } \\
\hline Handling infectious materials & $-.0306425^{*}$ & .0075 & 0.000 \\
\hline Breathing smoke & $-.0182422 *$ & .00858 & 0.034 \\
\hline Painful positions & $.0142121^{*}$ & .00683 & 0.037 \\
\hline Repetitive movements & $.0153894 *$ & .00636 & 0.016 \\
\hline Emotionally disturbing & $.0775271 *$ & .0076 & 0.000 \\
\hline \multicolumn{4}{|l|}{ Job Characteristics } \\
\hline Private sector & -.018536 & .02132 & 0.385 \\
\hline Public sector & -.021208 & .01959 & 0.279 \\
\hline Joint private-public & $-.0575955^{*}$ & .01584 & 0.000 \\
\hline Health & $.0874917 *$ & .0066 & 0.000 \\
\hline Precarious work & $.0135902 *$ & .00622 & 0.029 \\
\hline Armed forces & .0032417 & .0473 & 0.095 \\
\hline Managers & $.072912 *$ & .02335 & 0.002 \\
\hline Professionals & $.0499914 *$ & .01603 & 0.002 \\
\hline Technicians and associate professionals & $.0495404 *$ & .01613 & 0.002 \\
\hline Clerical support & $.068241^{*}$ & .01725 & 0.000 \\
\hline Service and sales & .0234809 & .01316 & 0.074 \\
\hline Skilled agricultural, forestry and fish & 0096701 & .0366 & 0.792 \\
\hline Craft and related trades & .0214978 & .01623 & 0.185 \\
\hline Plant and machine operators & .0009866 & .01575 & 0.950 \\
\hline \multicolumn{4}{|l|}{ Country } \\
\hline Austria & $-.1058774 *$ & .00587 & 0.000 \\
\hline Belgium & $-.0372969 *$ & .01048 & 0.000 \\
\hline Denmark & $-.1060287 *$ & .0059 & 0.000 \\
\hline Finland & $-.0741984 *$ & .00907 & 0.000 \\
\hline France & $.1128579 *$ & .01865 & 0.000 \\
\hline Germany & $-.1036219^{*}$ & .00683 & 0.000 \\
\hline Greece & $.2308237 *$ & .02952 & 0.000 \\
\hline Ireland & -.0083809 & .01499 & 0.057 \\
\hline Italy & .0001151 & .0171 & 0.995 \\
\hline Luxemburg & .0334112 & .01752 & 0.057 \\
\hline Netherlands & $.0397229 *$ & .01801 & 0.027 \\
\hline Portugal & $-.0432355^{*}$ & .01439 & 0.003 \\
\hline Spain & -.0121084 & .01154 & 0.294 \\
\hline Sweden & -.037847 & .01202 & 0.002 \\
\hline
\end{tabular}

Note: * means that the coefficient is statistically significant at $5 \%$ level of significance.

Females have a 3.71 percent higher probability of reporting anxiety than men. As age increases of one unit, the probability of reporting anxiety increases by 0.45 percent. Workers who have an illness or a health problem, which has lasted, or is expected to last, for more than 6 months have a 11.72 percent higher probability of reporting anxiety than workers who do not. Workers with secondary education have a 1.79 percent lower probability of reporting anxiety than workers with elementary education. Workers who live with the partner have a 2.46 percent lower probability of reporting anxiety than workers who live alone. 
As the number of people living in the household increases of one unit the probability of reporting anxiety decreases of 0.71 percent. Workers who perform a main job that involves complex tasks and who work to tight deadlines have respectively a 1.56 percent and a 1.78 percent higher probability of reporting anxiety than workers who do not. Who works more than 10 hours a day at least once a month, and on Sunday has respectively a 2.98 percent and a 1.37 percent higher probability of reporting anxiety. People working in free time to meet work demands (3.23 percent), people working without taking a break when wished (1.52 percent) and people performing monotonous tasks (4.05 percent) have a higher probability of experiencing anxiety. Receiving helps and supports by the manager ( 6.38 percent), receiving help by the manager in getting the job done (3.18 percent) and cooperation by the colleagues ( 8.47 percent) make the probability of experiencing anxiety lower. Being exposed to infectious materials and to smoke, fumes, powder or dust etc. makes the probability of reporting anxiety problems respectively lower by 3.06 percent and by 1.82 percent. Tiring or painful positions and repetitive hand or arm movements make the probability of reporting anxiety problems higher respectively by 1.42 percent and 1.53 percent.

Exposition to situations that are emotionally disturbing makes the probability of experiencing anxiety higher by 7.75 percent. People who work in a joint private-public company have a 5.75 percent lower probability of reporting anxiety than people working in the not-for-profit sector or in an NGO. Thinking that your work affects health and thinking that you might lose the job in the next 6 months make the probability of reporting anxiety problems higher respectively by 5.75 percent and by 1.35 percent. Managers ( 7.29 percent), professionals (4.99 percent), technicians and associate professionals (4.95 percent), clerical support workers (6.82 percent) have a higher probability of reporting anxiety problems than workers who are employed in elementary occupations. People working in Austria (10.58 percent), Belgium (3.72 percent), Denmark (10.60percent), Finland (7.62 percent), Germany (10.36 percent), Portugal (4.32 percent) and Spain (1.21 percent) have a lower probability of reporting anxiety problems than people working in the UK. People working in France (11.28 percent), Greece ( 23.08 percent) and in the Netherlands (3.97 percent) have a higher probability of reporting anxiety than people working in the UK.

\section{Discussion}

The study investigated the correlation between working conditions and anxiety, which is considered by the literature the most prevalent mental health condition (Bystritsky et al. 2013). The econometric analysis employed data from the Sixth European Working Conditions Survey realised in 2017 and focused on EU15. The concept of working conditions adopted in the paper is a broad one, however, the Demand-Control-Support model (Karasek and Theorell 1990) has been considered as theoretical framework.

We expected that better working conditions decrease the probability of reporting anxiety over the last 12 months. This was supported by our results that confirm other studies findings (Griffin et al. 2002; Paterniti et al. 2002; Stansfeld et al. 1997; Stansfeld et al. 1998). All considered components of the job demand impact positively on anxiety, i.e. high work intensity both in the form of long hours of work and in the form of performing demanding tasks, and the impossibility of taking a break when helpful, increase the probability of reporting anxiety (Sparks et al. 1997; Spurgeon et al. 1997). According to the literature (Hyde et al. 2006; Perlow and Williams 2003; Karasek et al. 1982), positive and supportive work environment may reduce workers anxiety and it is likely that could partially counteract negative effects of job demand. We considered three measures of social support on the job that could contribute to create a good climate at work, including in the analysis both relationships with colleagues and with the manager.

Results confirm that cooperation with colleagues and support and help from the manager reduce anxiety problems. In addition, several risks related to work were considered as potential source of anxiety and results are a bit puzzling with exposition to dangerous materials and to toxic fumes reducing the probability of reporting problems of anxiety and with painful positions and repetitive movements increasing it. Among unpleasant circumstances on the job, we also considered being in situations that are emotionally disturbing for workers: results show that workers who live such situations have a higher probability of reporting anxiety. As concerns the kind of job performed, some works provoke more anxiety than others do, this is likely because works are different, with some more demanding than others, and characterised by dissimilar job latitude and job support. 
Indeed, taking as reference group workers who perform elementary occupations, managers, professionals, technicians and associate professionals, and clerical support workers report to experience more anxiety problems. Such results are not in line with the literature (Sanne 2004; VicHealth 2012; Milner et al. 2013), according to which low skilled workers, employed in elementary sectors, as more exposed to the risk of anxiety. Surprisingly, looking at the sector, results show that people who work in a joint private-public company report less anxiety problems than people who work in the non-profit sector, which is generally characterized by more collaboration, by a better work environment and by the sharing of the objectives (Bassous 2014). As expected precarious work, in particular, the possibility of losing the job in the next months increases the probability of experiencing anxiety (Karasek and Theorell 1990; Strazdins et al. 2004). We also included in the empirical analysis, some socio economics explanatory variables, among them it could be interesting looking the result on gender, with women reporting more anxiety problems than men do. This result is in line with the literature (Mausner, Dorsch and Eaton 2000; Bildt and Miche'lsen 2002). Largely women report worse working conditions than men do, however results on anxiety seem due also to several social circumstances. In particular, women play a dual role, at home and at work; for women the probability of sexual harassment on the job and the risk of domestic violence are higher than for men; gender discrimination on the job produces lower wages and more job requests (ILO 2016). All this is likely to produce more anxiety problems than men experience.

\subsection{Policy implications}

Work is one of the major domains of our life: from work, many people get gratification and work gives a sense to their life, however, as seen, under certain circumstances, it can become also a reason of stress, which in turn, leads to anxiety problems. In particular, poor working conditions (high demand and low support) are likely to increase anxiety. Since consequences of anxiety problems regard not only workers, but influence also their families, firms within which they are employed, and the community where they live, interventions aimed both at avoiding causes of anxiety and at managing it are needed. As concerns workers, one of the side effects of anxiety is a decrease of productivity (due to decreased concentration, reduced motivation, and low job satisfaction) and an increase in absenteeism with consequent costs for firms. Therefore, investing public and private resources to detect (through screening programmes) risk factors or early signs of disease and to cope anxiety (WHO 2000) seems to be needed, especially within global labour markets, which are constantly and rapidly evolving.

Precautionary measures should be adopted at least on two sides. From one side workers should be helped to manage anxiety through specific educational programs, also teaching coping strategies of support for organisational changes. From the other side work environment should be constantly detected for highlighting and improving, in a healthy direction, adverse working conditions. On this way, within firms, the adoption of policies aimed at the promotion of mental wellbeing would be desirable. At the same time, policies promoting principles of collaboration among colleagues and with the boss that strengthen social support should be pursued. All the above recommendations and others are suggested by the WHO Global Plan of Action on Worker's Health (20082017) and by the Mental Health Action Plan (2013-2020) as global policy.

All the assumptions for encouraging workers well-being should be made, since "the gain to both individuals and the organization from promoting good mental health at work is reflected in increased presence, well-being and production" (WHO 2000).

\subsection{Strengths and limitations}

One the strengths of the paper is the large sample, which include a large set of countries: this allows providing a whole picture of the relationship between working conditions and anxiety in EU15. Most studies focus on single country or on groups of countries. At the same time, the large group of countries could imply a limitation since the sample aggregates together different countries with very different work related features within working contests sometimes very dissimilar among them. However, countries dummies were included in the empirical analysis and, considering the UK as reference group, in some countries workers report more anxiety problems than in others. This result is likely due to the different characteristics of each European labour market. Another strength of the paper is that it is the first time that EWCS6 data are investigated with the aim of exploring the association between working conditions and anxiety. To the best of our knowledge, there are no cross sectional studies on working conditions and anxiety implemented with much updated data as the EWCS6 data are. In addition, EWCS6 data are plenty of information on working conditions and this allows taking into consideration numerous aspects of the work environment. 
A limitation of the model is that the outcomes of the econometric analysis, a cross sectional study, describe a correlation rather than a cause-and-effect relation between working conditions and anxiety. We do not identify a clear causal relationship in one direction or the other, as association does not imply causation. However, calculation of the marginal effects, as discussed in Section 3, allows for interpreting the effect of the repressors on the dependent variable with interesting results. Moreover, as seen in Section 1, to the best of our knowledge, papers which have as dependent variable anxiety are very few, with most studies focusing on the relationship between working conditions and physical health and between working conditions and depression as a broad mental health disorder. Therefore, even with reported limitations, this study contributes to broaden the literature on working conditions and anxiety in a substantial manner.

\section{Conclusions}

Anxiety disorders are ranked as the sixth largest contributor to non-fatal health loss globally (WHO 2017). This paper studied the correlation between working conditions and anxiety in EU15. Results show that all considered measures of job demand are positively correlated with anxiety. Meaning that long working hours, job involving difficult and repetitive tasks increase the probability of reporting anxiety problems, same result for the possibility of losing the job. By contrast, a good occupational environment, where there is support of superiors and coworkers, decreases the probability of reporting anxiety problems. Moreover, results illustrate that there are differences among categories of workers with some categories reporting more anxiety problems than others do, this is likely to happen for more demanding jobs (managers, professionals, technicians and associate professionals, and clerical support workers). Several empirical analyses report that workers anxiety has costly consequences at individual level, at firm level and at societal level, however, extensive assessments of those costs are not available. Further research are needed both to evaluate all anxiety related costs and to detect proper ways to prevent on the job anxiety. The prevention of work related anxiety should became a public health priority.

\section{References}

Bandelow, B., Michaelis, S. (2015). Epidemiology of anxiety disorders in the 21st century. Dialogues in Clinical Neuroscience, 17 (3), 327-335.

Bardasi, E., Francesconi, M. (2004). The impact of atypical employment on individual wellbeing: evidence from a panel of British workers. Social Science and Medicine, 58 (9), 1671-88.

Barnay, T. (2014). Health, Work and Working Conditions: A. Review of the European Economic Literature, Economics Department Working Papers, No. 1148, OECD. Publishing, Paris. http://dx.doi.org/10.1787/5jz0zb71xhmr-en

Bassous, M. (2014). What are the Factors that Affect Worker Motivation in Faith-Based Non profit Organizations?. Voluntas, 26 (1), 355-381.

Baum, F. (1999). Social capital: Is it good for your health? Issues for a public health agenda, Journal of Epidemiology and Community Health, 53 (4), 195-196.

Bildt, C., Miche'1sen, H. (2002). Gender differences in the effects from working conditions on mental health: a 4year follow-up, International Archives of Occupational and Environmental Health, 75, 252-258.

Bystritsky, A., Khalsa, S.S., Cameron, M.E., Schiffman, J. (2013). Current Diagnosis and Treatment of Anxiety Disorders, Physical Therapy, 38 (1), 30-57.

Bosma, H., Peter, R., Siegrist, J., Marmot, M. (1998). Two alternative job stress models and the risk of coronary heart disease. American Journal of Public Health, 88 (1), 68-74.

Cheng, Y., Kawachi, I., Coakley, E., Schwartz, J., Colditz, G. (2000). Association between psychosocial work characteristics and health functioning in American women: prospective study. BMJ, 320 (7247), 1432-1436.

Cottini, E. (2012). Health at work and low - pay: A European perspective. Manchester School, 80 (1), 75-98.

Cottini, E., Lucifora, C. (2013). Mental Health and Working Conditions in Europe. ILR Review, 66 (4), 958-988.

Datta Gupta, N., Kristensen, N. (2007). Work environment satisfaction and employee health: panel evidence from Denmark, France and Spain, 1994-2001. European Journal of Health Economics, 9 (1), 51-61.

de Jonge, J., Kompier, MAJ. (1997). A Critical Examination of the Demand-Control-Support Model from a Work Psychological Perspective. International Journal of Stress Management, 4 (4), 235-258. 
De Lange, A.H., Taris, T.W., Kompier, M.A.J., Houtman, I.L.D., Bongers, P.M. (2004). The relationships between work characteristics and mental health: Examining normal, reversed and reciprocal relationships in a 4-wave study. Work \& Stress, 18 (2), 149-166.

Demerouti, E., Bakker, A.B., Jonge, J.D., Janssen, P., Schaufeli, W.B. (2001). Burnout and engagements at worksas a function of demands and control. Scandinavian Journal of Work, Environment \& Health, 27 (4), 279-286.

European Foundation for the Improvement of Living and Working Conditions, (2017), European Working Conditions Survey, 2015. [data collection]. 4th Edition. UK Data Service. SN: 8098, http://doi.org/10.5255/UKDA-SN-8098-4.

Fletcher, J.M., Sindelar, J.L., Yamaguchi, S. (2005).Cumulative Effects of Job Characteristics on Health. Health Economics, 20 (5) 553-570.

Griffin, J.R.F., Stansfeld, S., Marmot, M. (2002). The importance of low control at work and home on depression and anxiety: do these effects vary by gender and social class?. Social Science and Medicine, 54 (5), 783798.

Häusser, J.A., Mojzisch, A., Niesel, M., Schulz-Hardt, S. (2010). Ten years on: A review of recent research on the Job Demand-Control (-Support) model and psychological well-being. Work \& Stress, 24 (1), 1-35. https://doi.org/10.1080/02678371003683747

Hyde, M., Jappinen, P., Theorell, T., Oxenstierna, G. (2006). Workplace conflict resolution and the health of employees in the Swedish and Finnish units of an industrial company. Social Science and Medicine, 63 (2006), 2218-2227.

ILO (2016), WORKPLACE STRESS: A collective challenge.

Johnson, J.V., Hall, E.M. (1998). Job strain, work place social support, and cardiovascular disease: a crosssectional study of a random sample of the Swedish working population. American Journal of Public Health, 78 (10), 1336-1342.

Karasek, R.A. (1979). Job Demands, Job Decision Latitude, and Mental Strain: Implications for Job Redesign. Administrative Science Quarterly, 24 (2), 285-308.

Karasek, R.A., Theorell, T. (1990). Healthy Work: Stress, productivity, and the reconstruction of working life. New York: Basic Books, Inc.

Karasek, R.A., Triantis, K.P., Chandhry, S.S. (1982). Co-worker and supervisor support as moderation of association between task characteristics and mental strain. Journal of Occupational Behaviour, 3, 181200.

Llena-Nozal, A. (2009). The effect of work status and working conditions on mental health in four OECD countries. National Institute Economic Review, 209 (1), 72-87.

Mausner-Dorsch, H., Eaton, W.W. (2000). Psychosocial work environment and depression: Epidemiologic assessment of the Demand-Control Model. American Journal of Public Health, 90 (11), 1765-1770.

McKenzie, K., Whitley, R., Weich, S. (2002). Social capital and mental health. British Journal of Psychiatry, 181 (4), 280-283.

Milner, A., Spittal, M.J., Pirkis, J., LaMontagne, A.D. (2013). Suicide by occupation: Systematic review and meta-analysis. The British Journal of Psychiatry, 203 (6), 409-416.

Niedhammer, I., Chea, M. (2003). Psychosocial factors at work and self-reported health: comparative results of cross sectional and prospective analyses of the French GAZEL cohort. Occupational and Environmental Medicine, 60 (7), 509-515.

Ostry, A. S., Kelly, S., Demers, P. A., Mustard, C., Hertzman, C. (2003). A comparison between the effort-reward imbalance and demand-control models. BMC Public Health, 3 (1), 10-27.

Paterniti, S., Niedhammer, I., Lang, T., Consoli, S. (2002). Psychosocial factors at work, personality traits and depressive symptoms. Longitudinal results from the GAZEL Study. The British Journal of Psychiatry, 81 (2), 111-117.

Perlow, L., Williams, S. (2003). Is silence killing your company?. Harvard Business Review, 81 (5), 52-8.

Piasna, A. (2017). 'Bad jobs' recovery? European Job Quality Index 2005-2015, European Trade Union Institute. Working Paper 2017.06, https://www.etui.org/Publications2/Working-Papers/Bad-jobs-recoveryEuropean-Job-Quality-Index-2005-2015.

Piccinelli, M., Wilkinson, G. (2000). Gender differences in depression. Critical review. British Journal of Psychiatry, 177 (6), 486-492. 
Plaisier, I., de Bruijn, J.G., de Graaf, R., ten Have, M., Beekman, A.T., Penninx, B.W. (2007). The contribution of working conditions and social support to the onset of depressive and anxiety disorders among male and female employees. Social Science and Medicine, 64 (2), 401-10.

Robone, S., Jones, A.M., Rice, N. (2011). Contractual conditions, working conditions, health and well-being in the British Household Panel Survey. The European Journal of Health Economics, 12 (5), 429-444.

Rodriguez, E. (2002). Marginal employment and health in Britain and Germany: does unstable employment predict health?. Social Science and Medicine, 55(6), 963-79.

Rusli, B.N., Edimansyah, B.A., Naing, L. (2008). Working conditions, self-perceived stress, anxiety, depression and quality of life: A structural equation modelling approach. BMC Public Health, 8-48. https://doi.org/10.1186/1471-2458-8-48.

Sanne, B. (2004). Farmers are at risk for anxiety and depression: the Hordaland Health Study. Occupational Medicine, 54 (2), 92-100.

Sanne, B., Torp, S., Mykletun, A., Dahl, A.A. (2005). The Swedish Demand-Control-Support Questionnaire (DCSQ): factor structure, item analyses, and internal consistency in a large population. Scandinavian Journal of Public Health, 33 (3) 166-174. https://doi.org/10.1080/14034940410019217.

Siegrist, J. (1996). Adverse health effects of high effort-low reward conditions at work. Journal of Occupational Health Psychology, 1 (1), 27-43.

Sparks, K., Cooper, C., Fried, Y., Shirom, A. (1997). The effects of hours of work on health: a meta-analytic review. Journal of Occupation and Organizational Psychology, 70 (4), 391-408.

Spurgeon, A., Harrington, J.M., Cooper, C.L. (1997). Health and safety problems associated with long working hours: a review of the current position. Occupational and Environmental Medicine, 54 (6), 367-375.

Stansfeld, S., Fuhrer, R., Head, J., Ferrie, J., Shipley, M. (1997).Work and psychiatric disorder in the Whitehall II Study. Journal of Psychosomatic Research, 43 (1), 73-81.

Stansfeld, S., Head, J., Marmot, M.G. (1998). Explaining social class differences in depression and well-being. Social Psychiatry and Psychiatric Epidemiology, 33 (1), 1-9.

Stansfeld, S.A., Fuhrer, R., Shiple, M.J., Marmot, M.G. (1999). Work characteristics predict psychiatric disorder: Prospective results from the Whitehall II Study. Occupational Environmental Medicine, 56 (5), 302-307.

Strazdins, L., D’Souza, R.M., Lim, L.L.Y., Broom, D.H., Rodgers, B. (2004). Job Strain, Job Insecurity, and Health: Rethinking the Relationship. Journal of Occupational Health Psychology, 9 (4), 296-305. http://dx.doi.org/10.1037/1076-8998.9.4.296.

van der Doef, M., Maes, S. (1999). The Job Demand-Control-Support Model and psychological well-being: A review of 20 years of empirical research. Work \& Stress, 13 (2) 87-114. doi: 10.1080/026783799296084.

VicHealth (2012). Reducing stress in the workplace (An evidence review: summary report).Victorian Health Promotion Foundation, Melbourne, Australia.

Warren, J.R., Hoonakker, P., Carayon, P., Brand, J. (2004). Job characteristics as mediators in SES-health relationships. Social Science \& Medicine, 59 (7), 1367-1378.

Wilhelm, K., Kovess, V., Rios-Seidel, C., Finch, A. (2004).Work and mental health. Social Psychiatry and Psychiatric Epidemiology, 39 (11), 866-873.

WHO. (2000). Mental health and work: Impact, issues and good practices.

WHO. Comprehensive Mental Health Action Plan 2013-2020.

WHO. Global Plan of Action on Worker's Health (2008-2017).

WHO. (2017). Mental health in the workplace. 